\title{
SRGAP2 Gene
}

National Cancer Institute

\section{Source}

National Cancer Institute. SRGAP2 Gene. NCI Thesaurus. Code C131599.

This gene is involved in remodeling of the actin cytoskeleton. 